\title{
Quantification of Pollutant Levels in Water, Sediment and Winkles in Akani Obio Uruan River, Nigeria
}

\author{
Emmanuel Isaac Uwah ${ }^{1,2, ~ *, ~ E m e m ~ M i c h a e l ~ E d e m ~}{ }^{1}$, Iboroakam Essien Udosen ${ }^{3}$, \\ Essien Daniel Udosen ${ }^{1,2}$, Okon Monday Udoidiong ${ }^{4}$ \\ ${ }^{1}$ Department of Chemistry, University of Uyo, Uyo, Nigeria \\ ${ }^{2}$ International Centre for Energy and Environmental Sustainability Research (ICEESR), University of Uyo, Uyo, Nigeria \\ ${ }^{3}$ Department of Zoology, Akwa Ibom State University, Ikot Akpaden, Nigeria \\ ${ }^{4}$ Department of Fisheries \& Aquatic Environmental Management, University of Uyo, Uyo, Nigeria
}

Email address:

emmanueliuwah@uniuyo.edu.ng (E. I. Uwah), memsy4real2006@yahoo.com(E. M. Edem), piccolosen@yaoo.com (I. E. Udosen), essienandong $a$ yahoo.com (E. D. Udosen), omudoidiong@gmail.com (O. M. Udoidiong)

${ }^{*}$ Corresponding author

\section{To cite this article:}

Emmanuel Isaac Uwah, Emem Michael Edem, Iboroakam Essien Udosen, Essien Daniel Udosen, Okon Monday Udoidiong. Quantification of Pollutant Levels in Water, Sediment and Winkles in Akani Obio Uruan River, Nigeria. Science Journal of Analytical Chemistry. Vol. 8, No. 2, 2020, pp. 45-55. doi: 10.11648/j.sjac.20200802.12

Received: March 19, 2020; Accepted: April 13, 2020; Published: April 29, 2020

\begin{abstract}
The levels of some trace metals $(\mathrm{Cd}, \mathrm{Cr}, \mathrm{Cu}, \mathrm{Pb}$ and $\mathrm{Zn})$ were quantified in water, sediment and two species of winkles (Pachymelania bryonensis and Pachymelania fusca mutans) in Akani Obio Uruan River from August to September 2018 (wet season) and February to March 2019 (dry season), using Varian spectra 100 atomic absorption spectrophotometer. The levels of some physicochemical parameters (temperature, $\mathrm{pH}$, dissolved oxygen (DO), biochemical oxygen demand (BOD), electrical conductivity (EC), total dissolved solid (TDS), nitrate, sulphate and phosphate) were equally quantified in water. From the results, Cd level of $0.088 \mathrm{mg} / \mathrm{l}$ in water was higher than those of the other trace metals investigated. Accordingly, Cu level of $0.602 \mathrm{mg} / \mathrm{kg}$ in sediment was higher than $0.017 \mathrm{mg} / \mathrm{kg}$ in water and $0.077 \mathrm{mg} / \mathrm{kg}$ in one species of the winkles. Zn level of $0.141 \mathrm{mg} / \mathrm{kg}$ in one species of the winkles was higher than those of the other metals. In general, the levels of most of the metals were higher in all the samples during the wet season. This could be attributed to excessive water run-off during the wet season which could have resulted to the leaching of various kinds of wastes into the water bodies. Interestingly, the levels of all the trace metals investigated in all the samples were below the maximum acceptable limits stipulated by WHO and the US environmental protection agency (USEPA). Physicochemical examination revealed that the levels of $\mathrm{pH}$, temperature, TDS, EC, nitrate and sulphate were below the maximum permissible limits set by WHO. The levels of DO and phosphate in the water were however higher. This may have deleterious effect on aquatic ecosystem and the health of the rural dwellers that consumed the winkles and use the river water directly for domestic purposes without treatment.
\end{abstract}

Keywords: Quantification, Trace Metals, Pollution, Water, Sediment, Winkles

\section{Introduction}

Water pollution is any form of damage to the physical, chemical and biological characteristics of water which then affects the quality and suitability for any designated use or purpose [1]. The issues protection of water sources against faecal, agricultural and industrial contamination or pollution which is continually threatening the terrestrial and aquatic ecosystems due to increasing inputs of untreated wastes and chemical agents that are capable of causing damage to the environment are of great concern [2]. Rivers are of both ecological and economic significance to society. However, river waters are quite vulnerable to pollution because they are naturally open, 
easily accessible, and substantially used in agricultural, industrial, and municipal processes [3]. Environmental contaminants are introduced into the environment by many natural phenomena such as forest fires, volcanic eruptions and erosion, and by nearly all human activities. The toxic trace metals are the most common environmental chemical contaminants and the most often polluted environmental phases are the aquatic systems. This is because contaminants in the air, soil or on land ultimately end up in the aquatic systems via local precipitation, water runoff and leaching of rocks and solid wastes. The most common pathway by which aquatic systems receive wastes is, however, by direct discharge of urban and industrial wastes.

Trace metals are members of a subset of elements that have density above $5.0 \mathrm{~g} \mathrm{~cm}^{-3}$, exhibiting metallic properties and are chemically toxic to plants and animals [4]. The most important metals with regards to their potential toxic effects are $\mathrm{As}, \mathrm{Cd}, \mathrm{Cr}, \mathrm{Hg}, \mathrm{Pb}$ and $\mathrm{Zn}$; and metals which in small quantities are essential for healthy growth but when in excess become hazardous include $\mathrm{Co}, \mathrm{Cu}, \mathrm{Mn}, \mathrm{Ni}$ and $\mathrm{Se}$ respectively [5]. Trace metals are of particular concern due to their prevalent toxicity to aquatic organisms and are persistent in the environment [6]. The toxicity of the aquatic environment poses threat to man due to the fact that safe and suitable potable water supply for drinking and other uses are lacking especially in the rural settlement in Nigeria which makes rural dwellers to depend on rivers, streams, natural ponds, lakes, shallow hand-dug wells and harvesting of rain water to meet their water needs as well as depending on aquatic animals which are capable of bio-accumulating pollutants like trace metals as sources of food [7]. Human activities have caused levels of trace metals in the environment to increase. It is known that metal levels in biota are generally low, except in the vicinity of metal pollution [8]. Although aquatic ecosystems naturally contain trace metals essential for growth of aquatic organisms, the levels of these metals in seafood in recent times have increased due to anthropogenic inputs of domestic, chemical and industrial wastes often dumped indiscriminately into the aquatic environment. Levels of trace metals in aquatic environments and marine organisms have been of considerable interest because of their toxicity effect particularly on man.

Winkles are aquatic molluscs that are unsegmented, soft bodied and externally covered by hard calcareous shell that is segmented. The adults are benthic and their larvals are planktonic [9]. Winkles are usually found on mud flats in the water. Usually they are about $6 \mathrm{~cm}$ in length, and dark gray in colour. Like mudskipper fish, winkles are also valuable commercially. Their collections and marketing form an important industry in the Niger Delta of Nigeria. The nutritive values of winkles compare favourably with those of domestic livestocks and fish [10].
Winkles such as Pachymelania bryonensis and Pachymelania fusca mutans are mollusks of high economic value in Niger Delta of Nigeria. They are deposit feeders and bio-indicators of metals and hydrocarbon pollutions in the marine environment. Indeed winkles, like many aquatic organisms, have the ability to accumulate and biomagnified contaminants like trace metals.

Akani Obio Uruan River in Akwa Ibom State is within the braided stretch of the Cross River. Akani Obio Uruan settlement has a market located close to the shores where boats and canoes offload their catches after fishing trips. The Akani Obio Uruan River is indeed highly polluted as a result of incessant disposal of wastes such as human faeces, petroleum products from engine boats, and all forms wastes from markets, shops and surface water runoff. It is an established fact that sediment is a major sink for metals in aquatic environment [11]. Since winkles feed on the sediment, they stand a high risk of exposure to these toxic metals. This could pose a serious health risk to the large number of consumers in the coastal settlements who depend on these winkles and other seafood as their source major of protein supplement. This study was conducted to quantify the levels of some trace metals in water, sediment and two species of winkles (Pachymelania bryonensis and Pachymelania fusca mutans) in Akani Obio Uruan River with the view to ascertain the suitability of the winkles for human consumption in terms of trace metals contamination.

\section{Materials and Methods}

\subsection{Study Area}

The study was carried out at Akani Obio Uruan River (one of the rivers in the braided stretch of lower Cross River) in Uruan Local Government Area of Akwa Ibom State. The area is located on longitude $81^{\circ} 14 \mathrm{E}$ and latitude $50^{\circ} 87 \mathrm{~N}$ in south - south Nigeria. The river is situated downhill which makes it highly accessible to surface runoff from the boat repair shop wastes, human feaces, domestic wastes, open dump site wastes, and agrochemical wastes from agricultural farmlands. The inhabitants of the area enjoy only one season: the dry season. The wet season often poses a problem as the whole area is usually flooded during high tides. It begins in April through October with peak in July and August, while the dry season covers the period from November to March. During the wet season tremendous run off from the thinly vegetated slopes often carry with it a lot of wastes, resulting from all kinds of anthropogenic activities into water bodies which become polluted by them. Most of the inhabitants of this community depend on the river for their domestic needs, recreation and fishing. The study area is shown in Figure 1. 




Figure 1. The study area.

\subsection{Samples Collection}

Sampling was done between August and September, 2018 for wet season and February and March, 2019 for dry season. Water, sediment and two species of winkles (Pachymelania bryonensis and Pachymelania fusca mutans) were collected. Sampling was carried out at two (2) stations, namely: station one (1), representing the upstream and station two (2) representing the downstream. Three (3) water samples each of water from the upstream and downstream were randomly collected from three different points. Water samples for trace metal analysis were collected in nitric acid pre-rinsed (1L) containers and $5 \mathrm{~mL}$ of concentrated nitric $\left(\mathrm{HNO}_{3}\right)$ acid added immediately to minimize chemisorption. Water samples for Dissolved oxygen (DO) and biochemical oxygen demand (BOD) determinations were collected in amber bottles. In the field, the bottles were pre-rinsed with the water from the respective sampling sites. Water collection was done by dipping each mouth of the container against the flow direction to avoid trapping air bubbles in the bottle. Sufficient air spaces were left in all the bottles (except those for DO determination) to allow for expansion of water when the temperature increases [12]. A total of 36 water samples were collected for both the trace metals, DO and BOD analyses for one season and 72 for the two seasons.

Sediment samples were collected alongside the water samples at a depth of about $25 \mathrm{~m}$ using Van Veen grab sampler at three different points and made into composite samples. The sediment samples collected were stored in $1 \mathrm{~L}$ plastic containers. Winkles (Pachymelania bryonensis and Pachymelania fusca mutans) samples were handpicked along the river bank, washed immediately with the river water to remove mud and algae. Collected samples were properly labeled and kept in clean plastic containers and stored at $20^{\circ} \mathrm{C}$ before taking to the laboratory for analyses.

\subsection{Samples Preparation}

Sediment samples were air-dried and ground using porcelain mortar and pestle. The texturally equivalent petite fractions of the sediments were separated after grinding by sieving through a $2.00 \mathrm{~mm}$ mesh sieve. For each of the finely dried ground and sediment, $20 \mathrm{~g}$ kept in an air-tight plastic bottle prior to digestion.

The winkle samples were properly washed with distilled water to remove loosely held particles before the shells were broken using a stone. The edible parts including the filaments were removed, washed and placed in a conical flask and oven-dried at $60^{\circ} \mathrm{C}$ for 5 days. The dried samples were ground using plastic mortar and pestle. The finely ground winkle samples were stored in a well-labeled conical flask prior to digestion.

\subsection{Digestion of Sediment Samples}

From each of the finely ground sediment samples, exactly $1.0 \mathrm{~g}$ was digested in a mixture of nitric acid $\left(\mathrm{HNO}_{3}\right)$ and perchloric acid $\left(\mathrm{HClO}_{4}\right)$ in the ratio of 3:2 in a crucible and refluxed on a hot plate placed inside the fume hood at $110^{\circ} \mathrm{C}$ 
and was allowed to heat for 45 minutes till the mixture became clear. After heating, the resultant solutions and the undigested portion of the sediments were filtered using a filter paper. The filtrate was put in a volumetric flask and made up to $20 \mathrm{~cm}^{3}$ with deionized water. All the digested samples were stored in plastic bottles with plastic covers and labeled appropriately for trace metals analysis.

\subsection{Digestion of Winkle Samples}

From each of the finely ground winkle samples, exactly $1.0 \mathrm{~g}$ was weighed into a crucible. Exactly $10 \mathrm{~cm}^{3}$ of di-acid $\left(\mathrm{HNO}_{3}\right.$ and $\left.\mathrm{HClO}_{4}\right)$ in the ratio of $3: 2$ were added to the sample and placed on a hot plate inside the fume hood at $110^{\circ} \mathrm{C}$ and allowed to heat for 45 minutes until the mixture became clear. The resultant solution was later filtered and the filtrate transferred into a volumetric flask and made up to 20 $\mathrm{cm}^{3}$ with deionised water. All the digested winkle samples were stored in appropriately labeled plastic containers prior to trace metals analysis.

\subsection{Physicochemical Parameters Determination in the Water Samples}

The physicochemical parameters of the water samples were determined by standard procedures described by [13]. All field meters and equipment were checked and calibrated according to the manufacturer's specifications. The $\mathrm{pH}$ meter was calibrated using buffers of $\mathrm{pH} 4.0,7.0$ and 10.0 [14]. Total Dissolved Solid (TDS) meter was calibrated using the potassium chloride solution provided by the manufacturer [14]. In situ measurements for some of the parameters $\mathrm{pH}$, and temperature $\left({ }^{\circ} \mathrm{C}\right)$ were measured using WTW pH Electrode SenTix 41. While electrical conductivity (EC) and TDS was determined by using a C 0150 conductivity meter.

Dissolved oxygen (DO) in the water sample was determined by the Winkler's method. The biochemical oxygen demand (BOD) determination was done by keeping the water samples in an incubator in the dark for five days, after which the DO test was repeated and the BOD calculated by taking the difference between the initial and final concentrations of oxygen present after incubation as shown in Equation 1.

$$
\mathrm{BOD}_{5}(\mathrm{mg} / \mathrm{l})=\mathrm{DO}(\text { initial })-\mathrm{DO}(\text { final })
$$

The chloride content in water samples was determined by the Mohr's titration method. Exactly $1 \mathrm{~cm}^{3}$ of $5 \% \mathrm{~K}_{2} \mathrm{CrO}_{4}$ was added to $10 \mathrm{~cm}^{3}$ of water and titrated by constant stirring with $0.0282 \mathrm{M} \mathrm{AgNO}_{3}$ to brownish colour and compared with the blank. The chloride content was calculated using Equation 2.

$$
\mathrm{Cl}(\mathrm{mg} / \mathrm{l})=\frac{(A-B) \times M \times 70900}{\text { Volume of sample }(\mathrm{ml})}
$$

Where $\mathrm{A}=$ volume of $\mathrm{AgNO}_{3}$ used for titrating the sample, $\mathrm{B}=$ volume of $\mathrm{AgNO}_{3}$ used for titrating the blank and

$\mathrm{M}=$ Molarity of $\mathrm{AgNO}_{3}$.

Nitrite determination was done by measuring $10 \mathrm{~cm}^{3}$ of the water sample into a $25 \mathrm{~cm}^{3}$ conical flask and $1 \mathrm{~cm}^{3}$ of sulphanylamide solution added and allowed to stand for $2-8$ minutes. Exactly $1 \mathrm{~cm}^{3}$ of 1-naphthylethylene diamine reagent was added to the mixture and was allowed to stand for about 20 minutes and then made up to the $25 \mathrm{~cm}^{3}$ mark with deionised water. The absorbance was read at $543 \mathrm{~nm}$ using Jenway 7305 visible spectrometer.

Nitrate determination was done by measuring $10 \mathrm{~cm}^{3}$ of the water sample into a $25 \mathrm{~cm}^{3}$ conical flask and $2 \mathrm{~cm}^{3}$ of bruccine reagent added and followed with the addition of 10 $\mathrm{cm}^{3}$ concentrated $\mathrm{H}_{2} \mathrm{SO}_{4}$, mixed for about 30 seconds and allowed to stand for 20 minutes and then made up to the 25 $\mathrm{cm}^{3}$ mark with deionised water. The absorbance was read at $420 \mathrm{~nm}$ using jenway 7305 visible spectrometer. The Bruccine reagent was prepared by dissolving $1.0 \mathrm{~g}$ of bruccine sulpahte and $0.1 \mathrm{~g}$ of sulphanilic acid in $70 \mathrm{~cm}^{3}$ of hot distilled water and $3 \mathrm{~cm}^{3}$ concentration $\mathrm{HCl}$ added and the volume made up to $100 \mathrm{~cm}^{3}$ with distilled water.

Sulphate determination was done by the Gelatin method by measuring $10 \mathrm{~cm}^{3}$ of the water sample into a $25 \mathrm{~cm}^{3}$ conical flask and $1 \mathrm{~cm}^{3}$ of gelatin- $\mathrm{BaCl}_{2}$ reagent added. The sulphate was precipitated out as $\mathrm{BaSO}_{4}$ and the volume made up to the $25 \mathrm{~cm}^{3}$ mark with deionised water. The absorbance was read at $420 \mathrm{~nm}$ using jenway 7305 visible spectrometer.

Phosphate determination was done by the molybdenum blue method by measuring $30 \mathrm{~cm}^{3}$ of the water sample into a $25 \mathrm{~cm}^{3}$ conical flask and $3 \mathrm{~cm}^{3}$ of molybdenum blue reagent added and the volume made up to the $25 \mathrm{~cm}^{3}$ mark with deionised water. The absorbance was read at $885 \mathrm{~nm}$ using jenway 7305 visible spectrometer.

\subsection{Determination of Trace Metals in Water, Winkles and Sediment Samples}

The digest solutions of the water, winkles and sediment samples were prepared by measuring $10 \mathrm{~cm}^{3}$ of each of the samples into a $250 \mathrm{~cm}^{3}$ crucible. These were digested with aqua regia reagent $\left(\mathrm{HCl}\right.$ and $\left.\mathrm{HNO}_{3}\right)$, in the ratio of $3: 1$ at 130 ${ }^{\circ} \mathrm{C}$ using electric hotplate for 30 minutes. The filtrate was made up to $100 \mathrm{~cm}^{3}$ after filtration using a $100 \mathrm{ml}$ volumetric flask. Standard solutions of the metal to be analysed were prepared. The atomic absorption spectrophotometer (AAS) (model: varian spectra 100, Australia.) was set with power on for ten minutes. The standard metal solutions were injected to calibrate the AAS using acetylene gas. An aliquot of the digest solutions were injected and the concentrations obtained from the AAS.

\subsection{Data Analyses}

The data generated were subjected to statistical analyses using the Statistical Package for Social Sciences (SPSS) version 20.0 (SPSS Inc., Chicago, USA). Relationship between analysed physicochemical parameters, mean concentrations in the samples were investigated using Pearson correlation coefficient, $r$, at $\mathrm{P}<0.05$ and 0.01 significant levels. 


\section{Results and Discussion}

\subsection{Levels of Physicochemical Parameters in the Water Samples}

The levels of physicochemical parameters in the water samples obtained in this study are as presented in Table 1.

Table 1. Levels of some physicochemical parameters in the water samples.

\begin{tabular}{lllllll}
\hline Wet season & Dry season & & & & & \\
\hline Parameters & Station 1 & Station 2 & Mean & Station 1 & Station 2 & Mean \\
\hline Temp $\left({ }^{\circ} \mathrm{C}\right)$ & 28.80 & 28.72 & 28.76 & 29.40 & 29.48 & 29.44 \\
$\mathrm{pH}$ & 6.56 & 6.51 & 6.54 & 6.75 & 6.73 & 6.74 \\
TDS & 106.47 & 106.47 & 106.47 & 120.11 & 120.10 & 120.11 \\
EC $\left(\mu \mathrm{scm}^{-1}\right)$ & 5.07 & 5.06 & 5.07 & 7.23 & 37.22 & 37.23 \\
DO $(\mathrm{mg} / \mathrm{l})$ & 4.65 & 4.65 & 4.65 & 3.23 & 3.24 & 3.24 \\
BOD $(\mathrm{mg} / \mathrm{l})$ & 2.22 & 2.22 & 2.22 & 2.55 & 2.55 & 2.55 \\
Chloride $(\mathrm{mg} / \mathrm{l})$ & 3.84 & 3.84 & 3.84 & 29.45 & 29.45 & 29.45 \\
Nitrate $(\mathrm{mg} / \mathrm{l})$ & 0.32 & 0.22 & 0.27 & 0.02 & 0.02 & 0.02 \\
Nitrite $(\mathrm{mg} / \mathrm{l})$ & 0.72 & 0.44 & 0.58 & 0.02 & 0.02 & 0.02 \\
Sulphate $(\mathrm{mg} / \mathrm{l})$ & 0.85 & 0.68 & 0.77 & 0.01 & 0.01 & 0.01 \\
Phosphate $(\mathrm{mg} / \mathrm{l})$ & 0.86 & 6.07 & 6.07 & 5.02 & 4.88 & 4.95 \\
\hline
\end{tabular}

TDS $=$ Total dissolved solid, EC $=$ Electrical conductivity, $\mathrm{DO}=$ Dissolved oxygen, $\mathrm{BOD}=$ Biochemical oxygen demand

The mean $\mathrm{pH}$ levels of the water samples were 6.54 and 6.74 for wet and dry seasons, respectively. The mean temperatures were normal at 28.76 and $29.44^{\circ} \mathrm{C}$ for wet and dry seasons, respectively. Accordingly, the mean values for the electrical conductivity (EC) were 5.07 and $37.23 \mu \mathrm{scm}^{-1}$ for wet and dry seasons, respectively and the total dissolved solids (TDS) were found to be 106.4 and $120.0 \mathrm{mg} / \mathrm{l}$ for wet and dry seasons, respectively. The dissolved oxygen (DO) and biochemical oxygen demand (BOD) were found to be 4.7 $\mathrm{mg} / \mathrm{l}$ and $2.22 \mathrm{mg} / \mathrm{l}$ for wet season and $3.25 \mathrm{mg} / \mathrm{l}$ and 2.55 $\mathrm{mg} / \mathrm{l}$ during the dry season, respectively. The mean levels of nitrate, nitrite and phosphate in the water samples were 0.27 , 0.58 and $6.07 \mathrm{mg} / \mathrm{l}$, respectively for the wet season and 0.02 , 0.02 and $4.95 \mathrm{mg} / \mathrm{l}$, respectively for the dry season.

The toxicity level of a given biota is dependent on both the pollution source of the biota and the physicochemical properties of the given environment [15]. The $\mathrm{pH}$ of water is a measure of the concentration of its hydrogen ions. It is noted that $\mathrm{pH}$ level has implication on the bioavailability of metals in an aquatic medium [16]. High or low $\mathrm{pH}$ value in a river has been reported to affect aquatic life and alter the toxicity of the pollutant in one form or the other. The $\mathrm{pH}$ values of the studied water samples put the river as being weakly acidic. This could be attributed to the indiscriminate dumping of solid wastes in the surrounding lands. Accordingly, high natural production of humic acids and the lateritic soils of the river environment could contribute to the slightly acidic nature of the water body. This is agreement with the weakly acidic nature of water along Amadi Creek in Port Harcourt reported by [17]. However, the $\mathrm{pH}$ of the studied river water was below the WHO stipulated value [18] (WHO 2011). Temperature is an important factor which influences the chemical and biological characteristics of the aquatic system [19]. Knowledge of the temperature of a water body is significant because different aquatic organisms have different behavioural changes at different temperature ranges. It is known that an average temperature range of $25-$ $30^{\circ} \mathrm{C}$ is favourable for the survival of aquatic organisms [16].

$\mathrm{EC}$ is the ability of an aqueous solution to carry electric current. It gives information of all dissolved ions in solution. The dry season values of EC recorded in this study were generally higher than those of the wet season. This observation could be attributed to reduction in the volume of water during dry season. It could also be as a result of farming activities during wet season which involves the application of fertilizers to farmlands which are later leached into the river during the rains. The EC values recorded in this study were comparable to those reported in Etche River, Nigeria by [20]. The EC values of the water from all the sampling stations were below the guideline limit of 1500 $\mu \mathrm{scm}^{-1}$.

The level of DO in water signifies the potential for the oxidation of organic matter in the water and thus the ability of the water to support aquatic life [21]. The observed levels of DO in the water at all the sampling sites were below the permissible range of $8-10 \mathrm{mg} / \mathrm{l}$ given by WHO [18]. These levels of DO are attributed to high influx of organic wastes from domestic and agricultural run-offs. The higher DO values recorded in this study during the wet season could be due to the increased velocity and turbulent nature of the water in the sampling stations.

TDS are common indicators of water pollution. The values of TDS recorded in this study were above the permissible limit of less than $10 \mathrm{mg} / \mathrm{l}$ stipulated by WHO [18]. This could be attributed to storm water runoff, anthropogenic activities such as sand mining going on constantly in the river and atmospheric particle's deposits. TDS can be influenced by the $\mathrm{pH}$ of the water body [22]. Changes in the $\mathrm{pH}$ could cause some of the solutes to. precipitate or could affect the 
solubility of the suspended matter [22]. High TDS values in the wet season might be due to the increased runoff water from over flooding farmland. High TDS in a water body can also be attributed to washing of clothes and garbage dumping which are some common activities at the river bank in this area. These results were in agreement with those obtained in Qua lboe River Estuary by [23]. The results were also in agreement with those reported by [24] and [20].

Biochemical oxygen demand (BOD) is the amount of oxygen required to biologically break down a contaminant. BOD is therefore an important parameter of water indicating the health scenario of fresh water bodies [25]. The BOD values reported in this study are comparable to the values reported in Ismailia Canal, Egypt by [26]. In this study, the mean BOD value recorded was below the WHO limits of 10 $\mathrm{mg} / \mathrm{l}$.

\subsection{Levels of Trace Metals in Water, Sediment and Winkle Samples}

The levels of trace metals in water and sediment samples are presented in Figures 2 and 3, respectively and those of the winkles are presented in Figures 4 and 5. As seen in Figure 2, the results revealed that in water samples, levels of $\mathrm{Cr}$ ranged from 0.010 to $0.017 \mathrm{mg} / \mathrm{l}$ in each of the two stations for both wet and dry seasons. Levels of $\mathrm{Pb}$ were $0.005 \mathrm{mg} / \mathrm{l}$ in both stations in the wet season and below detectable limit in the dry season. While the Cd levels of 0.088 and $0.002 \mathrm{mg} / \mathrm{l}$ were recorded at stations 2 and 1 , respectively in the dry season and 0.086 and $0.087 \mathrm{mg} / 1$ at stations 2 and 1 , respectively in the wet season.

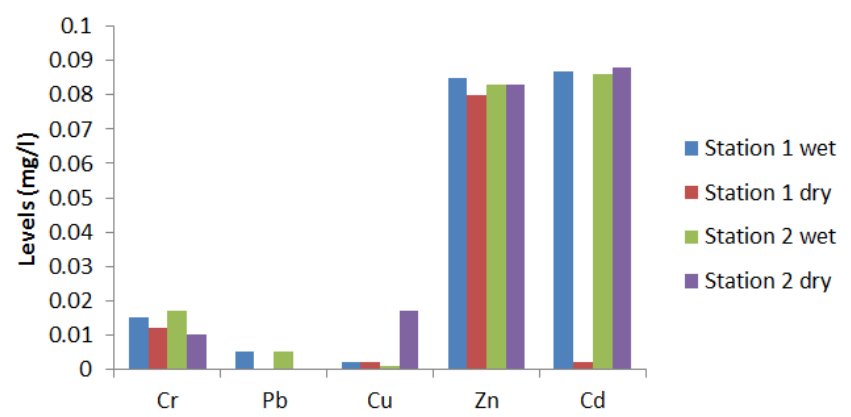

Figure 2. Levels (mg/l) of trace metals in water.

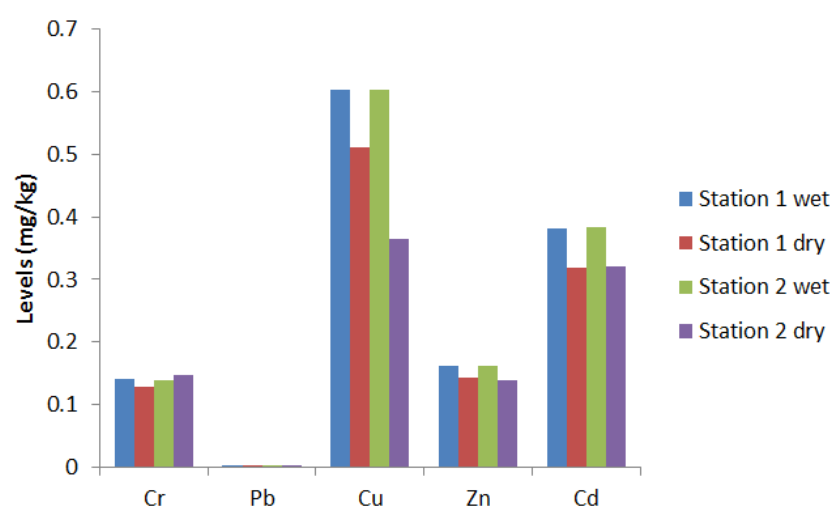

Figure 3. Levels ( $\mathrm{mg} / \mathrm{kg})$ of trace metals in sediment samples.

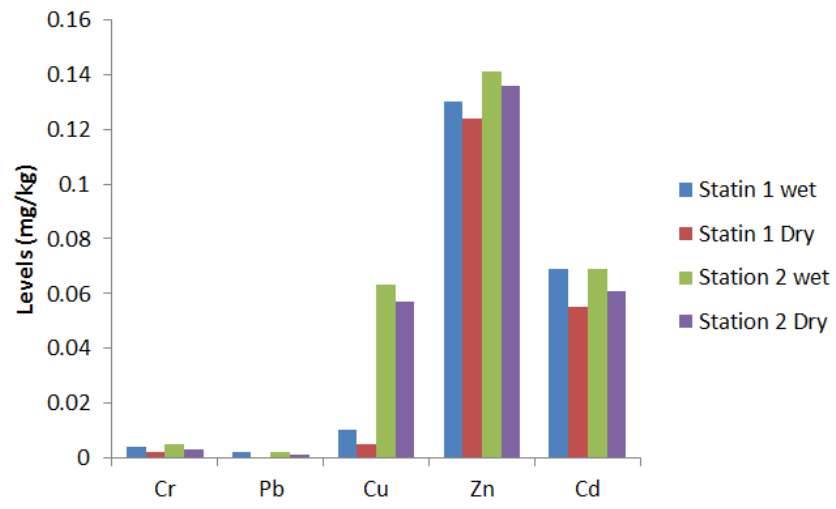

Figure 4. Levels $(\mathrm{mg} / \mathrm{kg})$ of trace metals in Pachymelania bryonensis.

In the sediment samples (Figure 3), levels of $\mathrm{Cr}$ were 0.140 and $0.139 \mathrm{mg} / \mathrm{kg}$ for wet season and 0.128 and 0.147 $\mathrm{mg} / \mathrm{kg}$ for dry season at stations 1 and 2, respectively. Levels of $\mathrm{Pb}$ were recorded as $0.001 \mathrm{mg} / \mathrm{kg}$ for both locations in the dry season and $0.002 \mathrm{mg} / \mathrm{kg}$ at station 2 in the wet season. $\mathrm{Cd}$ levels of $0.383 \mathrm{mg} / \mathrm{kg}$ were recorded at station 2 during wet season and $0.319 \mathrm{mg} / \mathrm{kg}$ recorded at station 1 during the dry season. Zn levels of $0.161 \mathrm{mg} / \mathrm{kg}$ were recorded for both stations during wet season and $0.138 \mathrm{mg} / \mathrm{kg}$ at station 2 during the dry season.

In the winkles, Cr levels of $0.042 \mathrm{mg} / \mathrm{kg}$ were recorded for Pachymelania fusca mutans (Figure 5) at station 2 in the wet season and $0.002 \mathrm{mg} / \mathrm{kg}$ at station 1 in the dry season. $\mathrm{Pb}$ levels of $0.002 \mathrm{mg} / \mathrm{kg}$ for both winkles at both stations during both seasons and it was below detectable limit at station 1 during dry season for Pachymelania bryonensis (Figure 4). $\mathrm{Zn}$ levels of $0.141 \mathrm{mg} / \mathrm{kg}$ were recorded for Pachymelania bryonensis at station 2 during wet season and $0.121 \mathrm{mg} / \mathrm{kg}$ recorded for Pachymelania fusca mutans at station 1 during dry season. Levels of $\mathrm{Cd}$ of $0.069 \mathrm{mg} / \mathrm{kg}$ were recorded for Pachymelania bryonensis at both stations during wet season and $0.012 \mathrm{mg} / \mathrm{kg}$ for Pachymelania fusca mutans at station 1 during dry season.

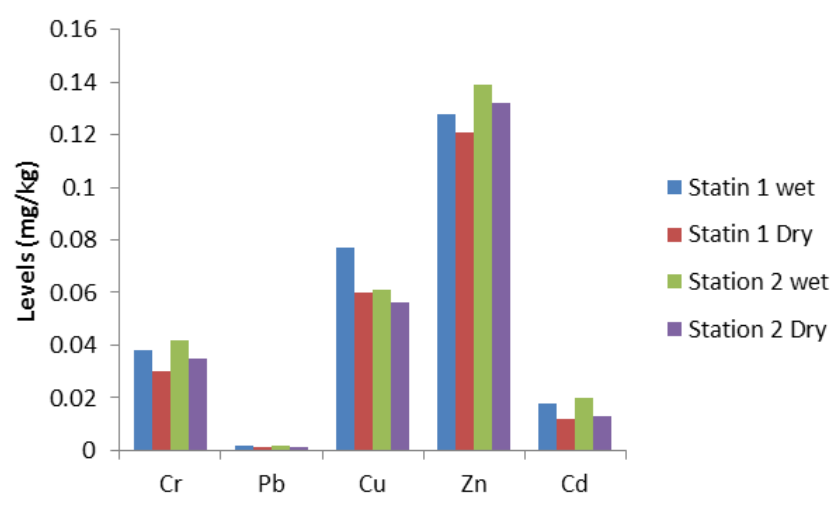

Figure 5. Levels (mg/kg) of trace metals in Pachymelania fusca mutans.

The levels of the investigated trace metals were generally low and within the permissible limits in all the samples. The levels of trace metals in an aquatic or terrestrial environment and consequent accumulation in organisms affect the survival of aquatic organisms in such environment and hence the toxic 
index of consumption of such aquatic organisms by humans [27]. Zinc $(\mathrm{Zn})$ is an essential element in our diet but a little or too much can be harmful.) $\mathrm{Zn}$ is a co-enzyme for over 200 enzymes involved in immunity, new cells growth and acidbase regulation [28]. The results obtained in this study showed that the levels of zn were higher in water compared to the winkles and sediment samples and that $\mathrm{Zn}$ levels were higher in the sediment samples during the wet season compared to the dry season. This could be attributed to excessive run-off during wet season which may have washed wastes laden with zinc from various sources into water body. The levels of zinc reported in this study are comparable to those reported in water and winkle from Lagos Lagoon, Nigeria by [29]. However, Zn levels for both seasons recorded in water, sediment and winkle samples in this study, were below the recommended values set by WHO, USEPA and FEPA. $\mathrm{Cu}$ is considered essential for normal growth and reproduction in animals and humans.

$\mathrm{Cu}$ is present in enzyme urease [30]. However, $\mathrm{Cu}$ - related health effects such as renal, cardiovascular, reproductive and immunological have been reported [19]. It is known that high levels of metals in sediment could be adduced from the fact that many of these metals are rapidly removed from water into the underlying sediment [29]. $\mathrm{Cu}$ level in sediment samples obtained in this study is higher than the value obtained in sediment collected from Okwumeshi River, Nigeria, reported by [31]. The domination by $\mathrm{Cu}$ in sediment compared with water and the winkles is in agreement with the concept that sediment is the sinks for a variety of pollutants and they allow contaminants that escape detection by water analysis to be identified [32]. In addition, it is observed that bottom sediment contains higher levels of metals than that of overlying water [31], The high $\mathrm{Cu}$ level in sediment samples recorded in this study during the wet season, could be attributed to the frequent rainfall during the wet season that leached $\mathrm{Cu}$ compounds and agricultural wastes from the nearby farmlands into the water body. However, the $\mathrm{Cu}$ levels for both seasons recorded in water, sediment and the winkles were all below the recommended international standards.

Chromium $(\mathrm{Cr})$ is an essential trace nutrient and a vital component of glucose factor but its toxicity damages the liver, lungs and causes organ haernorrhages [33]. The levels of $\mathrm{Cr}$ recorded in this study are comparable to those reported in Kpeshie Lagoon, Accra by [19]. The high value of $\mathrm{Cr}$ in sediment during dry season in this study suggests a reduction in the volume of water (dilution) during dry season which led to an increase in the level of the metal in sediment. More so, the high value of $\mathrm{Cr}$ in winkles during wet season could be attributed to increase in the level of the metal in the surrounding water and sediment leading to higher absorption by winkle due to increased feeding regime. However, the levels of $\mathrm{Cr}$ in all the samples in this study did not exceed the recommended limits by international and national bodies.

Lead $(\mathrm{Pb})$ is a toxic metal with no metabolic benefits to humans and aquatic biota. It has been documented to be among the most toxic trace metals in aquatic system. It is known that the presence of $\mathrm{Pb}$ in any compartment of the aquatic ecosystem indicates contamination [34]. The values of $\mathrm{Pb}$ obtained reported in this study are in agreement with those reported Qua Iboe River Estuary, Nigeria by [23]. In this study, level of $\mathrm{Pb}$ was generally low and below detectable limit during the dry season in water. This confirms the idea that pollutants particularly metals, tend to decrease along the distance of travel as they move through water [35]. Trace metals are distributed globally in different environmental matrices and the distribution varies according to locations. Comparing the trace metal levels in water, sediment and winkles of this study with other studies in Nigeria and other countries, indicated that the levels of the investigated trace metals in the water, sediment and winkles of the studied river were lower than those reported for Lagos Lagoon, Okwumeshi River (Nigeria) and Tekeze River Dam (Ethiopia) [36].

\subsection{Correlation Between the Physicochemical Parameters in Water}

The Pearson correlation matrixes of physicochemical parameters in water for wet and dry seasons are as presented in Tables 2 and 3, respectively. In the wet season, nitrite exhibited a strong positive correlation with nitrate (0.999) at $\mathrm{p}=0.01$ level of significance. Sulphate also exhibited strong positive correlation with nitrate and nitrite $(0.999)$ at $p=0.01$ level of significance. There was also a strong positive correlation between phosphate with nitrate, nitrite and sulphate $(0.999)$ at $\mathrm{p}=0.01$ level of significance. These indicated that nitrate, nitrite, sulphate and phosphate were influenced by the same sources (anthropogenic activities) of pollution in the same direction. Most of the parameters also showed high negative correlations, indicating that they are being influenced by the same sources (anthropogenic activities) of pollution but in the opposite direction, that is as one increases the other decreases. Weak positive or negative correlations were also seen between some of the parameters, indicating that such parameters are being influenced by different sources (anthropogenic activities) of pollution in the same or opposite direction, respectively. Similar results were observed during the dry season analysis.

\subsection{Correlation Between the Trace Metals in Water, Winkles and Sediment}

Correlations between the metals in water and sediment for wet and dry seasons are as presented in Tables 4 and 5, respectively. Similarly, correlations between the metals in winkles and sediment are as presented in Tables 6 to 9 for both the wet and dry seasons. As seen in the tables, some of the metals exhibited strong positive or negative correlations with each other, indicating that they are being influenced by the same sources (anthropogenic activities) of pollution in the same or in opposite directions. Accordingly, some of the metals exhibited weak positive or negative correlations with each other, indicating that they are being influenced by different sources (anthropogenic activities) of pollution in the 
same or opposite direction.

Table 2. Pearson's correlation matrix for physicochemical parameters in water during the wet season.

\begin{tabular}{|c|c|c|c|c|c|c|c|c|c|c|c|c|}
\hline & Temp & $\mathrm{pH}$ & Salinity & TDS & EC & DO & BOD & Chloride & Nitrate & Nitrite & Sulphate & Phosphate \\
\hline $\begin{array}{l}\text { Temp } \\
\text { pH }\end{array}$ & $\begin{array}{l}1 \\
-0.526\end{array}$ & 1 & & & & & & & & & & \\
\hline TDS & -0.471 & 0.834 & -0.552 & 1 & & & & & & & & \\
\hline $\mathrm{EC}$ & 0.273 & -0.824 & 0.629 & $-0.974 *$ & 1 & & & & & & & \\
\hline DO & -0.109 & 0.809 & -0.707 & $0.911 *$ & $0.979^{*}$ & 1 & & & & & & \\
\hline BOD & -0.075 & -0.766 & $0.973 *$ & -0.448 & 0.572 & -0.688 & 1 & & & & & \\
\hline Chloride & -0.244 & -0.619 & 0.662 & -0.716 & 0.855 & $-0.936^{*}$ & 0.724 & 1 & & & & \\
\hline Nitrate & $0.092 *$ & 0.433 & -0.711 & -0.131 & 0.086 & 0.006 & -0.696 & -0.012 & 1 & & & \\
\hline Nitrite & -0.106 & 0.433 & -0.706 & -0.132 & 0.090 & -0.000 & -0.688 & -0.000 & $0.999 * *$ & 1 & & \\
\hline Sulphate & -0.114 & 0.453 & -0.721 & -0.110 & 0.068 & 0.020 & -0.701 & -0.018 & $0.999 * *$ & $0.999 * *$ & 1 & \\
\hline Phosphate & -0.110 & 0.444 & -0.714 & -0.120 & 0.078 & 0.010 & -0.695 & -0.010 & $0.999^{* *}$ & $0.999 * *$ & $0.999 * *$ & 1 \\
\hline
\end{tabular}

** Correlation is significant at $\mathrm{p}=0.01$ (2-tailed), * Correlation is significant at $\mathrm{p}=0.05$ (2-tailed), Temp $=$ Temperature, TDS $=$ Total dissolved solid, EC $=$ Electrical conductivity, $\mathrm{DO}=$ Dissolved oxygen, $\mathrm{BOD}=$ Biochemical oxygen demand

Table 3. Pearson's correlation matrix for physicochemical parameters in water during the dry season.

\begin{tabular}{|c|c|c|c|c|c|c|c|c|c|c|c|c|}
\hline & Temp & pH & Salinity & TDS & EC & DO & BOD & Chloride & Nitrate & Nitrite & Sulphate & Phosphate \\
\hline Temp & 1 & & & & & & & & & & & \\
\hline $\mathrm{pH}$ & 0 & 1 & & & & & & & & & & \\
\hline TDS & 0.727 & -0.485 & 0.727 & 1 & & & & & & & & \\
\hline $\mathrm{EC}$ & 0.707 & 0 & 0.707 & 0.171 & 1 & & & & & & & \\
\hline DO & 0.855 & -0.366 & 0.855 & $0.977 *$ & 0.345 & 1 & & & & & & \\
\hline BOD & -0.786 & 0.436 & -0.786 & $-.995^{*}$ & -0.247 & $-0.992 *$ & 1 & & & & & \\
\hline Chloride & 0.816 & -0.408 & 0.816 & $0.990 *$ & 0.288 & $0.997 *$ & $-0.998 *$ & 1 & & & & \\
\hline Nitrate & -0.816 & 0.408 & -0.816 & $-.990 *$ & -0.288 & $-0.997 *$ & $0.998^{*}$ & -1 & 1 & & & \\
\hline Nitrite & 0 & 0.707 & 0 & -0.685 & 0.5 & -0.518 & 0.617 & -0.577 & 0.577 & 1 & & \\
\hline Sulphate & $0.904 *$ & 0.301 & $0.904 *$ & 0.365 & 0.852 & 0.552 & -0.447 & 0.492 & -0.492 & 0.426 & 1 & \\
\hline Phosphate & 0.450 & -0.631 & 0.450 & $0.940 *$ & -0.127 & 0.848 & $-0.905 *$ & 0.883 & -0.883 & -0.892 & 0.027 & 1 \\
\hline
\end{tabular}

** Correlation is significant at $\mathrm{p}=0.01$ (2-tailed), * Correlation is significant at $\mathrm{P}=0.05$ (2-tailed), Temp $=$ Temperature, TDS $=$ Total dissolved solid, $\mathrm{EC}=$ Electrical conductivity, $\mathrm{DO}=$ Dissolved oxygen, $\mathrm{BOD}=$ Biochemical oxygen demand,

Table 4. Correlation between metals in water and sediment during the wet season.

\begin{tabular}{|c|c|c|c|c|c|c|c|c|c|c|}
\hline & $\mathrm{SCr}$ & $\mathbf{S P b}$ & $\mathrm{SCu}$ & SZn & SCd & WCr & WPb & $\mathrm{WCu}$ & WZn & WCd \\
\hline $\mathrm{SCr}$ & 1 & & & & & & & & & \\
\hline $\mathrm{SPb}$ & 0.817 & 1 & & & & & & & & \\
\hline $\mathrm{SCu}$ & $-.919 *$ & -0.825 & 1 & & & & & & & \\
\hline $\mathrm{SZn}$ & $-.951 *$ & -0.857 & 0.790 & 1 & & & & & & \\
\hline $\mathrm{SCd}$ & 0.088 & -0.466 & 0.166 & -0.048 & 1 & & & & & \\
\hline WCr & $0.983 *$ & 0.774 & -0.831 & $-0.976^{*}$ & 0.194 & 1 & & & & \\
\hline $\mathrm{WPb}$ & -0.817 & -1 & 0.825 & 0.857 & 0.466 & -0.774 & 1 & & & \\
\hline WZn & -0.780 & -0.522 & $0.911 *$ & 0.553 & -.056 & -0.674 & 0.522 & -.426 & 1 & \\
\hline WCd & 0.061 & 0.565 & -0.335 & -0.061 & -.983 & -0.062 & -.565 & 0.594 & -0.126 & 1 \\
\hline
\end{tabular}

* Correlation is significant at $\mathrm{p}=0.05$ (2-tailed), $\mathrm{S}=$ sediment, $\mathrm{W}=$ water

Table 5. Correlation between metals in water and sediment during the dry season.

\begin{tabular}{|c|c|c|c|c|c|c|c|c|c|c|}
\hline & $\mathrm{SCr}$ & SPb & $\mathrm{SCu}$ & SZn & SCd & WCr & WPb & WCu & WZn & WCd \\
\hline $\mathrm{SCr}$ & 1 & & & & & & & & & \\
\hline $\mathrm{SPb}$ & -0.730 & 1 & & & & & & & & \\
\hline Scu & $0.948 *$ & -0.577 & 1 & & & & & & & \\
\hline $\mathrm{SZn}$ & 0.852 & -0.555 & $0.962 *$ & 1 & & & & & & \\
\hline $\mathrm{SCd}$ & 0.800 & -0.365 & $0.948 *$ & $0.973 *$ & 1 & & & & & \\
\hline WCr & 0.672 & -0.174 & -0.301 & -0.522 & -0.572 & 1 & & & & \\
\hline $\mathrm{WPb}$ & 0 & 0 & 0 & 0 & 0 & 0 & 1 & & & \\
\hline WZn & -0.427 & 0.878 & -0.169 & -0.097 & 0.106 & -0.560 & 0 & 0.891 & 1 & \\
\hline WCd & -0.730 & 0.333 & -0.577 & -0.333 & -0.365 & -0.522 & 0 & 0.609 & 0.292 & 1 \\
\hline
\end{tabular}

* Correlation is significant at $\mathrm{p}=0.05$ (2-tailed), $\mathrm{S}=$ sediment, $\mathrm{W}=$ water 
Table 6. Correlation between metals in Pachymelania bryonensis and sediment during wet season.

\begin{tabular}{|c|c|c|c|c|c|c|c|c|c|c|}
\hline & PBCr & PBPb & PBCu & PBZn & PBCd & $\mathrm{SCr}$ & SPb & $\mathrm{SCu}$ & SZn & SCd \\
\hline $\mathrm{PBCr}$ & 1 & & & & & & & & & \\
\hline $\mathrm{PBPb}$ & -.333 & 1 & & & & & & & & \\
\hline $\mathrm{PBCu}$ & 0.577 & -.555 & 1 & & & & & & & \\
\hline PBZn & 0.576 & -.626 & $0.996 *$ & 1 & & & & & & \\
\hline PBCd & 0.577 & 0.577 & 0.018 & -0.043 & 1 & & & & & \\
\hline $\mathrm{SCr}$ & -.730 & 0.730 & -0.298 & -0.356 & $-4.5 E-7$ & 1 & & & & \\
\hline $\mathrm{SPb}$ & 0.333 & -1 & 0.555 & 0.626 & -0.577 & -0.7303 & 1 & & & \\
\hline $\mathrm{SZn}$ & -.333 & 0.555 & 0.214 & 0.141 & 0.192 & 0.852 & -.555 & 0.962 & 1 & \\
\hline SCd & -.365 & 0.365 & 0.334 & 0.274 & $-4.5 E-7$ & 0.800 & -.365 & $0.948 *$ & $0.973 *$ & 1 \\
\hline
\end{tabular}

* Correlation is significant at $\mathrm{p}=0.05$ (2-tailed), $\mathrm{S}=$ sediment, $\mathrm{PB}=$ Pachymelania bryonensis

Table 7. Correlation between metals in Pachymelania fusca mutans and sediment in wet season.

\begin{tabular}{|c|c|c|c|c|c|c|c|c|c|c|}
\hline & PfmCr & PfmPb & PfmCu & PfmZn & PfmCd & $\mathrm{SCr}$ & $\mathbf{S P b}$ & $\mathrm{SCu}$ & SZn & SCd \\
\hline PfmCr & 1 & & & & & & & & & \\
\hline $\mathrm{PfmPb}$ & $0.997 *$ & 1 & & & & & & & & \\
\hline $\mathrm{PfmCu}$ & 0.426 & 0.408 & 1 & & & & & & & \\
\hline PfmZn & $0.988^{*}$ & $0.996^{*}$ & 0.417 & 1 & & & & & & \\
\hline PfmCd & $0.979 *$ & $0.970 *$ & 0.594 & $0.960 *$ & 1 & & & & & \\
\hline $\mathrm{SCr}$ & -0.270 & -0.316 & 0.645 & -0.340 & -0.076 & 1 & & & & \\
\hline $\mathrm{SPb}$ & 0.576 & 0.577 & -0.471 & 0.544 & 0.420 & -0.730 & 1 & & & \\
\hline $\mathrm{SZn}$ & 0.228 & 0.192 & $0.942 *$ & 0.181 & 0.420 & 0.852 & -0.555 & $0.962 *$ & 1 & \\
\hline $\mathrm{SCd}$ & 0.360 & 0.316 & $0.903 *$ & 0.289 & 0.536 & 0.800 & -0.365 & $0.948 *$ & $0.973 *$ & 1 \\
\hline
\end{tabular}

* Correlation is significant at $\mathrm{p}=0.05$ (2-tailed), $\mathrm{S}=$ Sediment, $\mathrm{Pfm}=$ Pachymelania fusca mutans

Table 8. Correlation between metals in Pachymelania bryonensis and sediment in dry season.

\begin{tabular}{|c|c|c|c|c|c|c|c|c|c|c|}
\hline & PBCr & $\mathbf{P B P b}$ & PBCu & PBZn & PBCd & $\mathrm{SCr}$ & SPb & $\mathrm{SCu}$ & SZn & SCd \\
\hline $\mathrm{PBCr}$ & 1 & & & & & & & & & \\
\hline $\mathrm{PBPb}$ & 0.632 & 1 & & & & & & & & \\
\hline $\mathrm{PBCu}$ & $0.999 * *$ & $0.999 * *$ & 1 & & & & & & & \\
\hline PBZn & $0.996 *$ & $0.996 *$ & $0.996 *$ & 1 & & & & & & \\
\hline PBCd & 0.639 & 0.639 & 0.627 & 0.601 & 1 & & & & & \\
\hline $\mathrm{SCr}$ & $0.928 *$ & $0.928 *$ & $0.934 *$ & $0.912 *$ & 0.437 & 1 & & & & \\
\hline $\mathrm{SPb}$ & 0.577 & 0.577 & 0.588 & 0.527 & 0.246 & 0.817 & 1 & & & \\
\hline SZn & -0.786 & -0.786 & -0.797 & -0.776 & -0.149 & -0.951 & -0.857 & 0.790 & 1 & \\
\hline $\mathrm{SCd}$ & 0.310 & 0.310 & 0.307 & 0.387 & -0.079 & 0.088 & -0.466 & 0.166 & -0.048 & 1 \\
\hline
\end{tabular}

** Correlation is significant at $\mathrm{P}=0.01$ (2-tailed), ${ }^{*}$ Correlation is significant at $\mathrm{P}=0.05$ (2-tailed), $\mathrm{S}=\mathrm{Sediment}, \mathrm{PB}=$ Pachymelania bryonensis

Table 9. Correlation between metals in Pachymelania fusca mutans and sediment in the dry season.

\begin{tabular}{|c|c|c|c|c|c|c|c|c|c|c|}
\hline & PfmCr & PfmPb & PfmCu & PfmZn & PfmCd & $\mathrm{SCr}$ & $\mathrm{SPb}$ & $\mathrm{SCu}$ & SZn & SCd \\
\hline $\mathrm{PfmCr}$ & 1 & & & & & & & & & \\
\hline $\mathrm{PfmPb}$ & -0.452 & 1 & & & & & & & & \\
\hline $\mathrm{PfmCu}$ & -0.863 & 0.665 & 1 & & & & & & & \\
\hline PfmZn & $0.964 *$ & -0.671 & $-0.909 *$ & 1 & & & & & & \\
\hline PfmCd & 0.613 & 0.258 & -0.140 & 0.440 & 1 & & & & & \\
\hline $\mathrm{SCr}$ & $0.938 *$ & -0.648 & -0.793 & $0.974 *$ & 0.546 & 1 & & & & \\
\hline $\mathrm{SPb}$ & $-0.957 *$ & 0.298 & 0.682 & -0.886 & -0.804 & $-0.919 *$ & 1 & & & \\
\hline $\mathrm{SZn}$ & -0.788 & 0.756 & 0.650 & -0.883 & -0.429 & -0.951 & 0.790 & -0.857 & 1 & \\
\hline $\mathrm{SCd}$ & 0.121 & -0.609 & -0.605 & 0.272 & -0.694 & 0.088 & 0.166 & -0.466 & -0.048 & 1 \\
\hline
\end{tabular}

* Correlation is significant at $\mathrm{p}=0.05$ (2-tailed), $\mathrm{S}=$ sediment, $\mathrm{Pfm}=$ Pachymelania fusca mutans

\section{Conclusion}

Based on the analyses and results, it is worth concluding that the water and sediment samples as well as the two species of winkles (Pachymelania bryonensis and
Pachymelania fusca mutans) analysed in this study contain variable levels of the investigated trace metals and physicochemical parameters. In general, the levels of most of the metals were higher in all the samples during the wet season. This could be attributed to excessive water run-off during the wet season which could have resulted to the 
leaching of various kinds of wastes into the water body. Interestingly, the levels of all the trace metals investigated in all the samples were below the maximum acceptable limits stipulated by WHO and the US environmental protection agency (USEPA). Physicochemical examination revealed that the levels of $\mathrm{pH}$, temperature, total dissolved solid (TDS), electrical conductivity (EC), nitrate and sulphate in the water were below the maximum permissible limits set by WHO. The levels of dissolved oxygen (DO) and phosphate in the water were however higher. This may have deleterious effect on aquatic ecosystem and the health of the rural dwellers that consumed the winkles and use the river water directly for domestic purposes without treatment. Correlation analysis between pairs of the investigated metals revealed that some of the metals exhibited strong positive or negative correlations with each other, indicating that they are being influenced by the same sources (anthropogenic activities) of pollution in the same or opposite direction. Accordingly, some of the metals exhibited weak positive or negative correlations with each other, indicating that they are being influenced by different sources (anthropogenic activities) of pollution in the same or opposite direction. Similar results were observed for the physicochemical parameters.

\section{References}

[1] Adefemi, S. O., Oyakhilome, G. I., Asaolu, S. S., and Aiyesanmi, A. F. (2013). Interrelationship of Heavy Metals Concentration in water, sediment and fish samples from Owena multi-purpose Dam, Ondo state, Southern Nigeria. Journal of Emerging Trend Engineering. Applied Science, 4 (2): 207-215.

[2] Matsumoto, S. T., Janaina, R., Mario, S. M., and Maria, A. M. (2005). Evaluation of the Genotoxic Potential due to the action of an Effluent Contaminated with Chromium, by the Comet Assay in CHO-K1 cultures. Caryologia, 58 (1): $40-46$.

[3] Li, Z., Mao, X. Z., Li, T. S., and Zhang, S. Y. (2016). Estimation of river pollution source using the space-time radial basis collocation method. Journal of Advanced Water Resource, 88: 68-79.

[4] Duffus, H. J. (2002). Heavy metals A meaningless Term. (IUPAC Technical Report), Journal of pure and Applied Chemistry, 74 (5): 493 - 507.

[5] James, C., and Ducan, M. (2002). Hand book of Green chemistry and Technology. Balwell publishing UK. 41-42.

[6] Barrie, M., Peake, k., and Jeffery N. B. (2006). Sources of heavy metals and polycyclic aromatic hydrocarbons in urban storm water runoff. Science of Total Environment, 359: 145155 .

[7] Ekere, N. R., Ukoha, P. O., Udeogu, U. V., and Agbazue, V. E. (2014). Potential health risk assessment of heavy metals $[\mathrm{Cd}$ $\mathrm{Cu}$ and $\mathrm{Fe}]$ concentrations in some important frozen fish species consumed in Nigeria. International Journal of Chemical Science, 12 (2): 366-374.

[8] Lindqvist, L., Block, M. (1995). Excretion of cadmium during moulting and metamorphosis in Tenebrio molitor (Coleoptera; Tenebrionidae). Comp Biochemical and Physical Science, 111:
325-328.

[9] Egborge, A. B. M. (1994). Water Pollution: Biodiversity and Chemistry of Warri River. Ben Miller Book Nig. Ltd Nigeria.

[10] Dambo, W. B. (1992). Tolerance of the Periwinkles Pachymelania aurita (Muller) and Tympanotonus fuscastus (Linne) to Refined oils. Environmental Pollution, 79: 293-296.

[11] Voogt, D. P., Feenstra, H. B., Copius, J. F., and Peerbom, J. W. (1980). Exposure and Health Effects of Cadmium. Toxicological and Environment Reviews, 3: 88 - 109.

[12] Udosen, E. D. (2015). Concepts in Environmental Chemistry. Aniko Global Ventures.

[13] Ademoroti, C. M. A. (1996). Environmental Chemistry and Toxicology. Foludex Press Ltd. Ibadan. 215p.

[14] HACH, 1997. Water Analysis Handbook. 3rd Edition., HACH Company, Loveland, Colorado, USA.

[15] Qu, L., Huang, H., Xia, F., Liu, Y., Dahlgren, R., Zhang, M. and Mei, K. (2018). Risk Analysis of Heavy Metal Concentration in Surface Waters Across the Rural - Urban interface of the Wen-Rui Tang River, China. Journal of Environmental Pollution, 237: 639-649.

[16] Namrata, S. (2010). Physicochemical Properties of Polluted water of River Ganga at Varanasi. International Journal of Energy and Environment. 1 (5): 823-832.

[17] Tubonimi, J. K., Omubo, A. and Herbert, O. S. (2010). Assessment of Water Quality along Amadi Creek in Port Harcourt, Nigeria. Sceintia Africana, 9 (1): 153-165.

[18] WHO (World Health Organisation) (2011). Children's Health and Environment. WHO training package for the Health Sector.

[19] Addo, M. A., Okley, G. M., Affum, H. A., Acquah S., Gbadageo, L. K. and Senu, J. K. (2011). Level of some Heavy Metals in Water and Sediments of Kpeshie Lagoon, La-Accra. Ghana. Research Journal of Environment and Earth Science, 3 (5): 487-497.

[20] Akintoye, O. A., Obi, C. N., Etim, O. A., Olorundam, T., Ukata, S. U. and Harrison, U. (2014). Seasonal Variation in the Physicochemical Characteristics of Surface Water in Etche River, Niger Delta Area of Nigeria. Journal of Environmental Science, Technology and Food Technology, 8 (7): 1-7.

[21] EPA (Environmental protection agency) (2003). Toxicological Profile for Zinc. Available at www.atsdr.cdc.gov/toxprofiles/tp60-c8pdf retrieved on $20^{\text {th }}$ February 2015.

[22] Ugwu, A. L. and Wakama, R. J. (2012). A Study of Seasonal Physicochemical Parameters in River Usma. American Journal of Environmental Science, 8 (5): 569-576.

[23] Dan, S. F., Umoh, U. U. and Osabor, V. N. (2014). Seasonal Variation of Enrichment and Contamination of Heavy Metals in the Surface Water of Qua Iboe River Estuary and Adjoining Creeks, South-South, Nigeria Journal of Oceanography and Marine science, 5 (6): 45-54.

[24] Adebola, A., Seun, M. A. and Oladele, O. (2013). Water Quality Assessment of River Ogun using Multivariate Statistical Techniques. Journal of Environmental Protection, 4: 446-478. 
[25] Bhatti, M. T. and Latif, M. (2011). Assessment of Water Quality of a River using Indexing Approach During the Low Flow Season. Irrigation Drainage, 60: 103-114.

[26] Abdo, M. H. and El-Nasharty, S. M. (2010). Physico-chemical Evaluations and Trace Metals Distribution in Water-surficial Sediment of Ismailia Canal, Egypt. Nature and Science, 8 (5): 1987-206.

[27] Li, S. and Zhang, Y. (2011). Risk Assessment and Seasonal Variations of Dissolved Trace Metals and Heavy Metals in the Upper Han River. China. Journal of Hazardous materials, 7: 1051-1058.

[28] Strachan, S. (2010). Trace Element. Current Anaesthesia Criteria care, 26: 44-48.

[29] Aderinola, O. J., Kusemiju, V. and Clarke E. O. (2011). Trace Metal Distribution in Surface Water, Sediment and Tissues of Fresh Water (Cat fish) (Clarias gariepinus) from Oke-Ofa canal, Lagos, Nigeria. International Journal of Geography and Geology, 1 (1): 10-22.

[30] Kumar, B. and Makherjec D. (2013). Assessment of Human Health Risk for $\mathrm{Ar}, \mathrm{Cu}, \mathrm{Ni} \mathrm{Hg}$ and $\mathrm{Zn}$ in Fish Collected from Tropical Wetlands in India. Advances in the Science and Technology, 2: 13-23.

[31] Ekeanyanwu, C. R., Ogbuinyi, C. A. and Etiengjirhevwe O. F. (2011). Trace Metals Distribution in Fish Tissue, Bottom
Sediments and Water from Okuemeshi River in Delta State, Nigeria Environmental Research Journal, 5 (1): 6-10.

[32] Deffew, 1., Mair, J. and Guzman, H. (2004). An Assessment of Metal Contamination in Mangrove Sediments and Leaves from Puntamal Bay Pacific Panama. Marine Pollution Bulletin, 50 (5): $547-552$.

[33] ATSDR (Agency for Toxic Substances and Disease Registry) (2000). Toxicological profile for chromium. Department of Health and Human services.

[34] Chong, Y., Xuan, X., Zhu, L., Wang, J; Goa, Y; Yang, K; Shen, X and Lou, B. (2013). Distribution of PAHs in Surface Water, Sediments and Soils of Hangzhou city, China, water Research, 38: 3558-3568.

[35] Tiimub, B. M., Bia, A. and Awuah, R. T. (2012). Some Physicochemical and Heavy Metals Concentration in Surface Water Stream of Tutuka in the Kenyasi Mining Catachment Area. International Journal of Development And Sustainability, 1 (2): 212-224.

[36] Desta, M. B., Asgedom, A. G. and Gebremedhim, Y. (2012). Health Risk Assessment of Heavy Metals Bioaccumulation in Water, Sedment and three Fish species (Labeobarbus spp. Clarias gariepinus and Oreochromus niliticus) of Tekeze River Dam, Tigray, Northern Ethiopia. Journal of Atmospheric and Earth Environment, 1 (1): 19-29. 